\title{
The Revitalisation of Water Resources for Sustainable Agricultural Development in South Africa: A review
}

\author{
Isaac Azikiwe Agholor ${ }^{1}$ \\ ${ }^{1}$ Department of Agricultural Economics, Extension and Rural Development, University of fort Hare, South Africa \\ Correspondence: Isaac Azikiwe Agholor, Department of Agricultural Economics, Extension and Rural \\ Development, University of fort Hare, South Africa. E-mail: isaaco477@yahoo.com
}

Received: January 21, 2013 Accepted: February 23, 2013 Online Published: April 15, 2013

doi:10.5539/jas.v5n5p76 URL: http://dx.doi.org/10.5539/jas.v5n5p76

\begin{abstract}
The promotion of efficiency and sustainability of water use have been enshrined in the National Water Act (Act 36 of 1998) of South Africa. Currently there is no immediate intractable water crisis facing South Africa, although this is undoubtedly based on the assumption that the existing water resources will be managed effectively. In enhancing revitalisation, the design and supervision of water resources must be linked with the country's development approach for sustained agrarian reform. It cannot, however, be applauded that the broad social and economic objectives, or even the more specific objective of water security, in South Africa are being fully realized at moment. However, to understand the contemporary issues in revitalisation of water resources for sustainable agricultural development, the paper first describes the various phases of irrigation development in South Africa and highlights the past and present measures taken by the government to ensure equity of access to water. Secondly, it also highlights water security; water demand and supply management; water productivity and water governance in South Africa.
\end{abstract}

Keywords: revitalisation, water resources, sustainable agriculture, governance and water security

\section{Introduction}

South Africa is the $29^{\text {th }}$ driest country out of 139 countries with $1110 \mathrm{~m}^{3}$ of water per capita in 2005 (Muller et al., 2009). The rainfall pattern is erratic and unequally distributed across the country. Water resource base supports intensive and subsistence agriculture, mining activities and other social and economic activities in both rural and urban areas of the country. The sphere of water flow is divided into green water (vapour) flows and blue water (run-off) flows. Currently, emphasis has been placed on the management of blue water, which is used for irrigation, mining and industries, and domestic as against green water which is erroneously assumed that it is of less value. Green water also sustains the ecosystem services like rain-fed agricultural production, forestry, fibres and grasses for livestock. Today, rain-fed agriculture which mainly depends on green water is embraced and practiced on $97 \%$ of the available agricultural land in Sub-Saharan Africa (SSA) notwithstanding, the positive postures of irrigated farming (FAO, 2002). It is unjustifiable to rely entirely on irrigation as a universal remedy for intensification of agricultural production and sustainability (FAO, 2002). The expansion of irrigation schemes has been in indeterminate state over the past 20 years, coupled with the degradation of irrigated crop land, mismanagement, difficulties in revitalisation and maintenance of infrastructures (FAO, 2002). Currently, South Africa is dependent on blue water (run-off or surface water) for its agricultural production and water security improvement. However, studies from "Water Reconciliation" asserted that blue water handiness is inadequate to support a developing economy (NWRS-2, 2012). In South Africa, the growth of blue water occurs in few water management areas whilst majority of the water management areas have no water. However, in some basins or watersheds were enough water is available, for instance the UThukela, Mzimvubu and Pongola, the proximity to areas of demand is not ideal coupled with the exorbitant cost of transmissions per cubic metre to areas of need (DWA, 2010). In addition, development of new dams and purchase of water resource equipment are costly coupled with arduous procedure that may take a decade from commencement to commissioning (DWA, 2010). In most municipalities, water that is classified as "non-revenue water" (free water) accounts for more than $37 \%$, and water losses accounts for approximately $50 \%$; while losses from domestic and irrigation schemes accounts for $60 \%$. In relations to loss in revenue, these losses amounts to about R11 billion per annum at the municipal level alone (NWRS-2, 2012). Water use through irrigation has decreased substantially from 80 to $50 \%$ in the last 25years (De Villers et al., 2004, 
Muller et al., 2009). Therefore, it is imperative to improve and revitalise water resources for sustained agricultural development and water security.

South Africa is water-scare, therefore, revitalization and increasing water availability for agricultural production becomes very necessary to assist in the generation of sustainable living. According to (Hamdy et al., 2003), the more we conserve water for agricultural production, the less the need for investment in water infrastructural development and the greater the local food security, and more water for agriculture, more for domestic and industrial uses. Revitalising water resources is therefore just one part of a wider unified sustainable rural development strategy. Soil depletion and insecurity of water resources has affected the livelihood of majority of people and the prospect of food security, with adverse consequences on sustainable agriculture. The ultimate problem for human race is to safeguard and manage the water resource base on which income, food, and raw materials production depends. The international community has acknowledged the need for a unified method to the security and sustainable management of land and water resources, as highlighted in "decision III/11 of the Conference of the Parties to the Convention on Biological Diversity" which encompasses all interested parties at local, national level, farmers, peasants and non-governmental organizations (UN, 1997). The term "water resources and water use' are used to succinctly illustrate in this review, that water use in agriculture is not only limited to irrigation but also encompasses the water that is harvested, soil water conservation and water for livestock production. The review paper therefore, dwells on a range of strategies and policy aspects adopted to revitalise the water resources for sustainable agricultural development in the following perspectives: Smallholder irrigation development, water resources in South Africa, water security and management, water demand and supply management, water productivity and water governance.

\subsection{Smallholder Irrigation Development}

The growth and development of smallholder irrigation schemes in South Africa have been characterised by definite government policies and different forms of technology which was associated with economic development (Backeberg \& Groenewald, 1995). The smallholder irrigation in South Africa existed in phases

\subsubsection{Peasant and Mission Diversion Phase}

The peasant and mission phase which started in the $19^{\text {th }}$ century was the first smallholder irrigation scheme to be developed and it was linked to missionary activities in South Africa (Bruwer \& Heerden, 1995). This phase also coincided with the existence of the individual diversion scheme era which was private and the technology used involves river diversion to farms (Backeberg \& Groenewald, 1995).

\subsubsection{Smallholder Canal Phase}

The canal phase of smallholder irrigation was developed together with the schemes using storage dams. The primary motive for establishing both schemes was to provide black and white families the opportunity to use agrarian activities as a means of livelihoods (Backeberg \& Groenewald, 1995). However, many of the smallholder irrigation schemes developed at this period were built after the Second World War and it was mainly aimed at providing African families residing in the "Bantu Areas" with a full livelihood (The Commission, 1955). The "Bantu Areas" which were formed as a result of the Land Act of 1913 and the Land and Trust Act of 1936, limited land ownership by the black South Africans to these zones. The irrigation water was obtained from the river and diverted to the field by a concrete canal conveyance system. Averagely, the plot size on the schemes ranges from 1.28 to 1.71 hectares for the black farmers while the white counterparts had an average plot size of 8 hectares to 20 hectares (Van Averbeke et al., 2006). The variance in plot size between black and white farmers indicated that irrigation design was carried out under the notion that black farmers and their families needed less land than the white families to reach a complete livelihood (Backeberg \& Groenewald, 1995). This second phase of irrigation development lasted from 1930 to 1960 and it was noted as the public storage irrigation scheme. In 1952, about 122 smallholder irrigation schemes have been built or under construction, with total land area of 11406 hectares comprising a sum of 7538 plots holders (The Commission, 1955). According to The commission (1955), a total of 54051 hectares of land in these areas had the prospect for irrigation development and could settle almost 36000 farming families, representing about 216000 farmers. A total of 18200 hectares of irrigated land was developed during this phase (Arcus Gibb, 2004).

\subsubsection{Independent Homeland Phase}

The independent homeland phase of smallholder irrigation development which formed an essential part of economic development of the homelands existed from 1970 to 1990. The homeland which had its origin from the "Bantu Areas" made provision for both traditional and language cluster. The homelands were granted autonomy but dearth of development and poverty was very pronounced in the inlands and therefore it became pertinent to 
improve their economy by the creation of new irrigation schemes as a development strategy ((Beinart, 2001). However, funding of these irrigation schemes was provided by South Africa government (Lahiff, 2000). According to Arcus Gibb (2004), not less than 64 of the existing irrigation schemes, with a total land coverage of 13000 hectares, were built at this phase. Nevertheless, the number of smallholder irrigation schemes that existed at this period may be more, as records were not properly documented. This phase was noted for purposeful and centralised scheme management, large irrigation scheme with technical development (Backeberg \& Groenewald 1995). The large scheme which was more than 500 hectares were established mainly in the Eastern Cape and comprised of the scheme situated at Keiskammahoek, Tyefu, Xonxa and Ncora (Van Averbeke et al., 1998). The large schemes established during the sovereign homeland period were costly to maintain. However, following the democratisation of South Africa in 1994, the provincial governments decided to dissolve the agricultural homeland parastatals that were inherited. This decision led to the total collapse of production in the large schemes (Laker, 2004).

\subsubsection{Irrigation Management Transfer (IMT)}

The primary focus of irrigation development in the early 1990s was for food security and poverty alleviation. The study carried out by Arcus Gibb (2004) showed that they were approximately 62 new irrigation schemes established at that period. The Independent Development Trust played a major role in the funding of these irrigation projects but later the Provincial department of Agriculture, public works and health department took over the funding (Van Averbeke \& Mei 1996). At this period, the Reconstruction and Development Programme (RDP) as an economic development programme of government mandated for community based projects collaborated with Irrigation Management Transfer (IMT) to enhance the living condition of the people and to empower them to take over the control and maintenance of the existing irrigation projects in their areas. The primary aim of the IMT is to transfer entirely the duty of supervision, operation and maintenance of irrigation schemes to the farmers. However, the transfer of these responsibilities requires revitalisation of the irrigation schemes. In many parts of the world, IMT were also implemented as an approach to irrigation scheme management with the aim of increasing the lucrativeness of irrigated agriculture and to reduce the continuing government spending on the operation and maintenance of the irrigation schemes (Shah et al., 2000). The Revitalisation of these irrigation schemes stems from the WaterCare programme that was launched in 1998. The aim of the WaterCare programme was to revitalize selected smallholder irrigation schemes not only in the area of infrastructure but also in governance and productivity (Arcus, 2005).

\section{Water Resources in South Africa}

Rainfall in South Africa is usually irregular and occurs during the summer with almost all agricultural activities been dependent on irrigation. The total annual surface water run-off resulting from rainfall is approximately 50 150 million $\mathrm{m} 3$ per year, however, with the construction of dams average water storage capacity of 27000 million $\mathrm{m} 3$ has been attained (DWAF, 2009). The annual water usage in South Africa stood at 22, 400 million m3 while the percentage used for irrigation is approximately $50 \%$. For instance, the average yearly rainfall is about $500 \mathrm{~mm}$ with the Central and Eastern regions of South Africa experiencing summer rainfall, while the Western region of the country experience winter rainfall (DAF 2010). Most crops has varying degrees of water requirement, for example while about $15 \mathrm{~kg}$ of maize grain is produced with one millimetre of water consumed (Du Plessis, J., 2003), cabbage and soya bean production cycle water requirement vary from 380 to 500 and $500 \mathrm{~mm}$ to $900 \mathrm{~mm}$ respectively (DAF, Cabbage/Soya bean Production guide lines 2010). The National water Act (Act 36 of 1998), which became effective in October the same year, produced a framework for ensuring that South Africa's water resources are managed in such a way to benefit its citizenry. The fundamentals to be considered in ensuring that this happens include (DWAF, 1998): "Meeting the basic human needs of present and future generations; promoting equitable access to water; redressing the results of past racial and gender discrimination; promoting the efficient, sustainable and beneficial use of water in the public interest; facilitating social and economic development; and providing for the growing demand for water use". These fundamental recipes recognise that equilibrium has to be struck in the allocation between different groups of users. Social and economic growth will be enhanced when water is allocated and used efficiently. The Water Users Associations (WUAs) was formed primarily to allow communities to pool their financial and human effort together to be able to carry out water related activities. It is stipulated that the WUA would assist in water distribution role, maintenance, and collection of water supply charges (DWAF, 2000).

\section{Water Security and Management}

Water security has been defined as "the reliable availability of an acceptable quantity and quality of water for health, livelihoods and production, coupled with an acceptable level of water-related risks" (Grey \& Sadoff, 2007). 
In order to secure water availability and use, South Africa adopted a new water policy which climaxed the promulgation of National Water Act-NWA (Act 36 of 1998). The new NWA permits the government to remain as the trustee of the nation's water resources and also functions in the public trust to guarantee that water is "protected, used, developed, conserved, managed and controlled in a sustainable and equitable manner for the benefit of all persons" (DWAF, 2000). The freedom to use water is however, granted to users, who must be registered and licensed after paying the prescribed fee. Nevertheless, the main idea of water management under the new Act is decentralization with security measures in water distribution for basic human requirement and development purposes. In ensuring the effective devolution of water, Nineteen Water Management Areas have been delineated countrywide under the auspices of Catchment Management Agencies (CMAs) with the mandate to ensure the sustainable use of water resources in their areas of operation, in line with the aims of the Act. At the community and smallholder farmers' levels, every user are allowed to take water for "reasonable domestic use, gardens and livestock watering" (but not for commercial purposes) without registration, licensing or paying fee, as specified in the Act.

\section{Water Demand and Supply Management}

Water scenery is a resource in itself, supporting many activities, particularly irrigation agriculture, nature conservation, and construction, as well as other livelihoods of the community. Water is obviously essential to economic growth and sustainable development of a country. In water demand management, each user sector has a variety of alternatives for control. This control is necessary because of limited groundwater supply resulting from surface runoff (Schreiner, 1998).

\subsection{Household Category}

The demand management system at the household category encompasses tariff adjustment upwards (to discourage consumption); changes in living arrangements (use of smaller plot size); and control of water losses through leakages at the Municipal distribution level; other demand management activities are: maintenance of household water fittings; and the regulation of the water use efficiency of household by creating awareness and encouraging the use of devices such as machines used for washing clothes (DWAF 2002).

\subsection{Industrial Category}

The water demand control and accounting in industries are made by proper metering. The "Government Notice $\mathrm{R}$ 22355 dated 8/06/2001" published in terms of Water Acts, is an essential document that oversees both industrial and local consumption of water (DWAF (2002). The guidelines specify that water to any consumer must be measured by means of a water-volume measuring apparatus (meter). The accessibility of water and consistency of supply, rather than costs, are usually the main concerns of industries. For big industries however, the policy stipulates that such industry must cover the full costs of making water available and this has assisted government to focus on water use efficiency. In addition, the policy allowed many industries to treat municipal waste water for reuse in their operations.

\subsection{Agriculture Category}

Agriculture is the largest water user in South Africa and measures have been put in place to regulate and manage its demand in the sector. As exemplified in most smallholder irrigation projects, there has been considerable progress in the efficacy of water use. For instance water scheduling practice which entails the timing of irrigation event and the control of irrigation water released has been adopted in most smallholder irrigation schemes. In addition, the use of advanced equipment and the cost placed on irrigation water indirectly act as an encouragement for improving the efficiency of water use. Improved efficiency in water use would make more water accessible for agricultural production thus enhancing better returns on investment. The adoption of stiff water pricing may lead to disastrous effect for poor farmers and most urban household. However, water marketing and pricing arrangement are considered beneficial in the search for higher water productivity (Jury \& Vaux, 2005).

\subsection{Water Supply Management}

The utilisation of water resources in South Africa is increasing and has necessitated concerted effort towards sustained supply. However, increases in water supply have been achieved through the following: (i) Storage: South Africa's storage size is quite well established, with a dam capacity of over 32 billion $\mathrm{m} 3$. This is approximately two-thirds of the average yearly flow in all its rivers. (ii) Water transfer: Water transmission, both within one river basin and from other river basins to another has been developed broadly in South Africa. The notable example is the Vaal River, which is augmented with water conveyed from the Orange River through the Lesotho Highlands Water Scheme. Related transfers happened in other areas such as Gauteng, the Nelson Mandela Metro in the Eastern Cape and other areas in North West and Limpopo provinces. (iii) Recycle of wastewater: The recycling of 
waste water is another supply management options which is extensively practice in South Africa. (iv) Naturally endowed water is also a source of additional water supply. In South Africa, legislation has been put in place to conserve enough water in rivers for environmental sustenance. The maintenance and sustainability of "environmental flows" has been come imperative with a view of protecting aesthetic attractions, such as the country's national parks.

\section{Water Productivity}

Water productivity is the totality of water used within a system, measured in terms of physical, economic or social values. "It is the measure of the economic, livelihood or biophysical output derived from the use of a unit of water" (Machibya et al., 2004). Water could be put into various uses such as irrigation, brick preparation, mining and domestic. The physical dimension denotes the output such as yield of crop for every amount of water exhausted in producing this yield. Economic measure is feasible when the physical output is converted to monetary terms or value under market situation. The social productivity is realistic when the value of water is likened to social benefits that are obtained as exemplified by the number of jobs created as a result of the existence of water or the worth of decent health realised through good sanitation by using water (DWAF 2000). The improvement of water productivity is hinged on the following conditions (i) "increasing the saleable yield of the crop for each unit of water transpired by it; (ii) reducing all outflows (e.g. drainage, seepage and percolation), including evaporative outflows other than the crop stomata transpiration; and (iii) increasing the use of rainfall, stored water, and water of marginal quality" (National Water Resource Strategy) (NWRS-2, 2012). The first condition has to do with the need to raise crop yield. The second condition is the intention to reduce losses of water while the third condition implies adoption of substitute for water resources. "The Comprehensive Assessment of Water Management in Agriculture (2007)" measured water productivity at the following levels: "crop/plant or animal; field/pond; farm/ agricultural enterprise; irrigation system; basin and landscape". Water resource management should have a way of distributing, reassuring efficient practice and overseeing the use of water in obliging the collective necessities of the society (Lenton \& Muller, 2009). There have been recorded feats in encouraging rainwater harvesting technologies in a variety of measures from "on-farm micro-catchment" to communal "macro-catchment" method in Sub-Saharan Africa (Malesu et al., 2007). There is also possibility for additional investment to encourage "up-scaling and out-scaling" of water harvesting initiatives while inducement programmes such as "working for water" might be a platform to develop water harvesting in South Africa (Poras et al., 2008). According to Lenton and Muller (ibid) results of enhanced water management will typically be discovered outside the water sector and there must be a linkage between planning of water resources and sustainable progress in the society.

\section{Water Governance}

Water Governance encompasses an array of political, social, economic and managerial processes over which varied interests are expressed, inputs are engrossed, decisions are made and applied, and decision makers (government) are answerable in the management and delivery of water resources at diverse levels of the society (Nowlan \& Bakker, 2007). Water governance is all about drawing and implementation of the right laws and policies from health, food security to land use and conservation of the natural environment on which water resources absolutely depend (UNDP, 2012) Ideal water governance entails obviousness, involvement, transparency, fairness, liability, consistency, awareness, unification and virtuous decision making (NWRS-2, 2012). In South Africa, there have been pragmatic changes in the governing structure and institutional arrangements since 1994. Despite these seeming changes, the water sector is still wallowing in numerous challenges (NWRS-2, 2012). These analysis, nurtures the government confidence that these crises can be ward off by refining water resource use and management. However, the undertaking to surmount these challenges will involve substantial changes in the ways water resources are developed, allotted, and administered. The proposal enunciated by the National Water Resource Strategies (NWRS-2, 2012) was to design and sustain enviable changes in the water sector to address the financial, environmental and capacity limitations inherent in the sector. Even though much has been accomplished in the water sector since 1994, the performance and results of the sector in relation to the sector objective have not been encouraging. However, considerable improvement in increasing access to water and cleanliness (sanitation) among some communities has been made, but the impact of this progress has not been felt as majority of South Africans are without water. Water stress and distribution of water for agriculture and industrial use are still highly lopsided and unequal (NWRS-2, 2012), with vagueness and dearth of transparency with respect to institutional roles and responsibilities contributing to meagre performance. Feebleness of governance is another underlying factor affecting agricultural water productivity (Booth, 2005). In ameliorating these challenges, it is pertinent to engage both official and implementation concerns in the water resource sector. The National Water Act of 1998 and the Water services Act are presently under review with an understanding of overcoming a number of challenges confronting the water sector (NWRS-2, 2012). An ideal 
water governance rest on robust and responsible sector management, a strong supervisory structure, and operative water management bodies with distinct roles and responsibilities.

\section{Conclusion}

Integrated water resource management and revitalisation is important keystone to sustainable agricultural development. It is necessary to address the policy framework and supportive actions at both farm and watershed levels. The termination of the traditional gap in improving water productivity does not necessarily mean the transfer of better know-hows to farmers, but entails putting proper institutional arrangements in place to allow farmers access to water use efficiency. Management of water resources involves contribution of all stakeholders, investing in infrastructure and the unrelenting effort and commitment of men and women in all segment of the society (Lenton \& Muller, 2009). The Millennium Development Goals on alleviation of poverty, food safety and ecological security are fundamental pointers to sustainable livelihood. The paper therefore, suggest that there is no immediate intractable water crisis facing South Africa; although this is clearly based on the assumption that the existing water resources will be managed efficiently. It is imperative that water losses should be reduced by embracing water loss reduction process such as: water supply and demand management, enhanced water governance and optimum use of available water resources (blue water, green water, rainwater harvesting, re-use of water, and desalination process). In the interim, it cannot however, be said that the country's broad social and economic objectives, or even the more specific objective of water security, are being fully realized. Nevertheless, the DWAF has therefore, introduced a programme for the promotion of Water for Growth and Development (WfGD) Framework. The necessity for such a framework is exemplified across the dimensions of social parity, livelihoods and agricultural productivity. With poverty as a social malaise that is taking its turn among majority of the citizenry, it is desirable that many opportunities inherent in the water sector should be utilised effectively for development and enhanced livelihood. However, if water security is to be achieved, revitalisation and the development of water resources must be guaranteed via action plan for the benefit of all. It is only then, will South Africa be seen as "water secured". The good news is that the DWAF has further initiated a strategy referred to as Water Conservation and Demand Management (WC\&DM), geared towards revitalisation of water use and productivity (DWAF, 2000).

\section{References}

Arcus, G. (2004). Principles, Approaches and Guidelines for the Participatory Revitalisation of Smallholder Irrigation Schemes. Year 1 Progress Report, WRC Project No. K5//1463/4. Arcus Gibb, Berea, East London.

Arcus, G. (2005). A Comparative Analysis of South African and International Irrigation Revitalisation Approaches. Report No 10 (draft) of WRC Project K5/1464//4.

Backeberg, G. R., \& Groenewald, J. A. (1995). Lessons from the Economic History of Irrigation Development for smallholder settlement in South Africa. Agrekon, 34(4), 167-171. http://dx.doi.org/10.1080/03031853.1995.9524805

Beinart, W. (2001). Twentieth-century South Africa. Oxford: Oxford University Press.

Booth, D. (2005) The report of the Africa Commission: What about politics? Overseas Development Institute, London.

Bruwer, J., \& Van Heerden. P. (1995). Spotlights on Irrigation development in RSA: the past, present and future. In: Southern African irrigation symposium, Durban, 4-6 June. WRC Report No. TT 71/95. Water Research Commission, Pretoria.

De Villiers, M. C., Eloff., J. F., Barnard, R. O., Mulibana, E., Mkhize, S., \& Msomi., B. (2004). Land and Water Management: South Africa situation analysis. In: C. Nhira, \& A. Mapiki (Eds.), Regional situational analysis: land and water management in the SADC Region. Workshop Proceeding, 1, 93-112.

Department of Water Affairs and Forestry. (2000). Water is life, Sanitation is dignity. Draft Report October, 2000.

Department of Water Affairs and Forestry. (2002). Guidelines for the Implementation of Water conservation/water demand management in the water services sector. Department of Water Affairs \& Forestry

Department of Water Affairs and Forestry. (1998). National Water Act (Act No. 36 of 1998). Government Printer, Pretoria.

Department of Water Affairs and Forestry. (2009). Water for Growth and development Framework, Pretoria.

Department of Water Affairs, South Africa. (2010). Overview.

Department of Water Affairs, South Africa. (2012). Water Quality management. 
Du Plessis, J. (2003). Maize production. Directorate of Agricultural Information service, Department of Agriculture, in cooperation with ARC-Grain crops Institute, Potchefstroom

Food and Agricultural Organisation [FAO]. (2002). Agriculture: Towards 2015/30. Technical Interim Report, FAO, Rome.

Grey, D., \& Sadoff, C. (2007). Sink or Swim? Water Security for Growth and Development. Water Policy, 9(6), 545-571. http://dx.doi.org/10.2166/wp.2007.021

Hamdy, A., Ragab, R., \& Scarascia-Mugnozza, E. (2003). Coping with Water scarcity: Water Saving and increasing water productivity. Irrigation/drainage, 52, 3-20. http://dx.doi.org/10.1002/ird.73

Jury, W. A., \& Vaux, H. (2005). The Role of Science in Solving the World's emerging Water Problems. Proceedings National Academy of Science, 102(44), $15715-15720$. http://dx.doi.org/10.1073/pnas.0506467102

Lahiff, E. (2000). An Apartheid Oasis? Agricultural and rural livelihoods in Venda. London: Frank Cass Publishers.

Laker, M. C. (2004). Development of General Strategy for optimizing the Efficient use of Primary Water resources for effective Alleviation of Rural poverty. WRC Report No KV149/04. Water Research Commission, Pretoria.

Lenton, R., \& Muller, M. (2009). Integrated Water Resources Management in Practice: Better Management for Development. Earthscan, London, UK.

Machibya, M., Mdemu, M., \& Lankford. (2004). Draft Irrigation Efficiency and Productivity manual tools for irrigation professionals and practitioners. Water and Irrigation Productivity Training, Mbeya, RIPARWIN Project.

Malesu, M. (2007). Mapping the Potential of Rainwater Harvesting Technologies in Africa. ICRAF Technical Manual No 7. World Agro-forestry Centre, Nairobi.

Muller, M., Schreiner, B., Smith, L., Van Koppen, B., Sally, H., Aliber, M., ... Pietersen, K. (2009). Water security in South Africa: Development Planning Division. Working Paper Series No.12, DBSA: Midrand.

Nowlan, L., \& Bakker. L. (2007). Delegating Water Governance: Issues and Challenges in the BC Context. Program on Water Governance. University of British Columbia.

Poras, I., Grieg-Gran, M., \& Neves, N. (2008). All that Glitters: A review of payments for watershed services in developing countries. IIED, London.

Schreiner, B. (1998). Water conservation \& demand management in South Africa: An overview. In (Anon) Workshop on Water conservation \& demand management, Environmentek, CSIR, Pretoria.

Shah, T., Van Koppen, B., Merrey, D., De Lange, M., \& Samad, M. (2002). Institutional alternatives in African smallholder irrigation: Lessons from international experience with irrigation management transfer. Research Report 60. International Water Management Institute, Colombo.

The Commission for the Socio-Economic Development of the Bantu Areas within the Union of South Africa. (1955). Summary of the report. Report U.G. 61/1955.

United Nations. (1997). General Assembly 19th Special Session. New York, 23-27 June Resolution Adopted By the General Assembly.

United Nations Development Programme [UNDP]. (2012). Water Governance Facility.

Van Averbeke, W., \& Mei, P. (1996). Evaluation of Masizakhe Agricultural Project: An Irrigated community garden in Lingelihle Township, Cradock. Agricultural and Rural Development Research Institute (ARDRI) Report 1/98.), University of Fort Hare.

Van Averbeke, W. M., Marete., C. K., Igodan, C. O., \& Belete, A. (1998). An investigation into Food Plot Production at Irrigation Schemes in Central Eastern Cape. Water Research Commission Report No. 719/1/98. 